J ournal of GovemmentandPditical Studies

Volume 2 - N0. 2 - Oktober 2019

P-ISSN: 2614-2120 E-ISSN: 2614-2104

\title{
Collective Action NGO dalam Pencegahan Korupsi Pengadaan Barang dan Jasa Pemerintah di Sulawesi Selatan
}

Rifaid

STIA Mataram

Jl. Bung Karno No.60, Pagesangan Timur, Kota Mataram. rifaid@stiamataram.ac.id

Zaldi Rusnaedy

Universitas Pancasakti Makassar

Jl. Andi Mangerangi No.73, Mamajang Dalam, Kota Makassar. makezaldy@gmail.com

Received: 9th September 2019; Revised: 1st October 2019;

Accepted: 2nd October 2019;

\begin{abstract}
This article discusses the collective action of NGOs in guarding and advocating corruption cases in South Sulawesi, specifically the procurement of Center Point of Indonesia (CPI) goods/services. The NGOs in the coalition are engaged in collective action in guarding the corruption of CPI, in which the group is focused on behalf of the Anti Corruption Community Coalition (KMAK) of Sulawei, incorporated from various NGOs namely ACC Sulawesi, PeRAK Institute, KOPEL Indonesia, FIK Non-Governmental Organizations and YASMIB Sulawesi. Media engagement is key to KMAK's success in guarding the CPI corruption, as an aggregation method to achieve its goals. The mass media coverage of reports, monitoring and discussions conducted by KMAK has made a number of formal state institutions take a look at the CPI case. The solid movement established by KMAK has transformed into a civil society movement that maintains a common goal of guarding the procurement of goods and services.
\end{abstract}

Keywords: NGO; public procurement; collective action.

\begin{abstract}
Abstrak
Artikel ini menjelaskan tentang collective action NGO dalam mengawal dan mengadvokasi kasus korupsi di Sulawesi Selatan, khususnya kasus pengaadaan barang/jasa Center Point of Indonesia (CPI). Dengan menggunakan metode penelitian kualitatif, penelitian ini menunjukan tindakan kolektif yang dilakukan NGO dalam mengawal dugaan korupsi CPI yaitu dengan cara berkoalisi, dan kelompok NGO tersebut mengatasnamakan Koalisi Masyarakat Anti Korupsi (KMAK) Sulawesi, yang tergabung dari berbagai NGO seperti (ACC Sulawesi, PeRAK Institute, KOPEL Indonesia, FIK Ornop Sulsel dan YASMIB Sulawesi) sebagai bentuk collective action. Keterlibatan media menjadi kunci keberhasilan KMAK Dalam mengawal kasus korupsi CPI, dan juga sebagai metode agregasi untuk mencapai tujuannya. Massifnya pemberitaan media atas laporan, pemantauan dan diskusi-diskusi yang dilakukan oleh KMAK membuat sejumlah lembaga formal negara ikut melirik kasus CPI tersebut. Solidnya gerakan yang dibangun oleh KMAK bertransformasi menjadi gerakan masyarakat sipil yang mempertahankan tujuan bersama yaitu mengawal kasus pengadaan barang dan jasa.
\end{abstract}

Kata kunci: NGO; pengadaan publik; collective action. 


\section{PENDAHULUAN}

Korupsi menjadi isu yang vital dalam kehidupan berbangsa dan bernegara di Indonesia. Korupsi sampai sekarang masih sulit untuk dipecahkan dan diberantas oleh pemerintah melalui aparat penegak hukum. Hal tersebut dikarenakan korupsi dilakukan secara sistematis, terencana dan terorganisir oleh para koruptor (Prasetya, 2015). Korupsi bukan lagi menjadi fenomena baru di Indonesia, sebab korupsi sudah sejak lama menjadi bagian aktivitas penyimpangan yang dilakukan oleh para pejabat publik. Terutama penyimpangan dalam proyek-proyek pengadaan barang/jasa pemerintah untuk memenuhi keuntungan pribadi dan kelompoknya (Butarbutar, 2018).

Salah satu sektor yang menjadi tumbuh suburnya praktik Korupsi, Kolusi dan Nepotisme (KKN) yaitu pada sektor pengadaan barang/jasa pemerintah. Hasil dari survei Indonesia Procurement Watch (IPW) yang dilaporkan di Komisi Pemberantasan Korupsi (KPK) Maret 2011, bahwa 89\% penyedia barang/jasa pemerintah melakukan suap pada panitia/pejabat pengadaan untuk memenangkan tender pemerintah. Penyimpangan yang terjadi pada pengadaan barang/jasa pemerintah selalu berujung pada tindakan korupsi (Setyadiharja, 2014).

Olson dengan collective action theory memberikan pendapat bagaimana melakukan pencegahan praktik korupsi pengadaan barang/jasa. Pendekatan teori collective action merupakan cara untuk menganalisis proses hubungan dinamika antara aktor-aktor politik atau kelompok-kelompok kepentingan dalam proses kebijakan tata kelola pengadaan barang dan jasa. Teori collective action hadir untuk menganalisis hubungan dinamika antara aktor-aktor yang terlibat dalam sebuah proses public procurement. Dalam pengadaan barang dan jasa, sesungguhnya banyak aktor dan kelompok yang terlibat. Keterlibatan banyak kelompok merupakan prasyarat keberhasilan collective action dalam mencegah korupsi (Olson, 2008; Sandler, 2015, Barnaud et al, 2018).

Ostrom dalam (Sandler, 2015) mengajukan dua proporsi collective action dalam pencegahan korupsi pengadaan barang/jasa. Pertama, ukuran kelompok. Kelompok yang dibangun dengan ukuran besar akan sulit mencapai kerjasama dalam tindakan kolektif, artinya semakin besar ukuran suatu kelompok kepentingan, maka akan sulit bagi kelompok tersebut menegosiasikan kepentingan diantara anggota kelompok. Demikian sebaliknya kelompok yang dibangun dengan ukuran kecil akan bekerja lebih efektif dalam mencapai tindakan kolektif. Ukuran kelompok, diukur dari formasi kelompok, teknologi/metode agregasi dan sumber anggaran. Kedua, ukuran kelompok. Anggota kelompok yang besar dengan beban kerja besar akan sulit mencapai tindakan kolektif. Karena keragaman anggota kelompok juga sangat berpengaruh terhadap efektifitas tindakan kolektif, jadi homogenitas kepentingan akan memudahkan kerja suatu kelompok. Komposisi kelompok dilihat dari keragaman kepentingan dan tujuan kelompok.

Collective action hadir sebagai salah satu cara untuk mengganti dan melengkapi, serta memperkuat peraturan dalam public procurement dan praktik anti korupsi yang lemah. Collective action merupakan metode yang telah teruji untuk memerangi korupsi. Sudah banyak contoh negara yang menerapkan pendekatan collective action untuk memerangi korupsi, baik di bidang privat procurement maupun public procurement, seperti Mexico, Ekuador, Jerman, dan Norwegia (Alto, 2010). 
Di Idonesia, kasus korupsi pengadaan barang/jasa merata di semua provinsi di Indonesia, termasuk di Sulawesi Selatan. Grafik peningkatan kasus korupsi di Sulawesi Selatan setiap tahunnya mengalami peningkatan. Data yang dirilis oleh ACC Sulawesi, setidaknya ada 118 kasus korupsi pengadaan barang/jasa selama periode 2013-2016. Seperti yang terlihat pada tabel di bawah ini.

Tabel 1.

Catatan Akhir Tahun Anti Corruption Committee (ACC) Sulawesi Korupsi Pengadaan Barang/Jasa di Provinsi Sulawesi Selatan Tahun 2013-2016

\begin{tabular}{cccc}
\hline No. & Tahun & \multicolumn{1}{c}{ Sektor } & Jumlah \\
\hline 1 & 2013 & Pengadaan barang/ jasa & 17 \\
\hline 2 & & & 45 \\
\hline 3 & 2015 & Pengadaan barang/ jasa & 56 \\
\hline 4 & 2016 & Pengadaan barang/ jasa & 118
\end{tabular}

Sumber : Anual report Anti Corruption Committe (ACC) 2013-2016

Laporan dan data lembaga atau instansi pemerintah maupun NGO tersebut terkait korupsi pengadaan barang/jasa khususnya di Sulawesi, menunjukan bahwa pelakasanaan pengadaan barang/jasa di Sulawesi Selatan belum maksimal. Melihat masih tinggginya presentasi korupsi yang terjadi pada sektor pengadaan barang/jasa di Sulawesi Selatan. Dengan demikian, sangat penting keterlibatan elemen masyarakat dalam pencegahan dan penindakan korupsi. Hal tersebutlah yang membuat tindakan kolektif NGO menjadi begitu penting untuk mengawal proses pengadaan barang/jasa pemerintah agar dapat berjalan secara transparan, akuntabel dan bebas dari praktik KKN (Astuti, 2014).

Tidak sedikit NGO yang memiliki komitmen dalam mengawal dan mengadvokasi kasus-kasus korupsi di Sulawesi Selatan. Sampai saat ini beberapa NGO masih konsisten mengawal kasus-kasus korupsi, diantaranya adalah ACC Sulawesi, KOPEL Indonesia, PerAK Institute, FIK Ornop dan YASMIB Sulawesi. NGO-NGO tersebutlah yang sangat mendukung upaya pemberantasan korupsi. Berkaitan dengan masalah tersebut, peneliti melakukan penelitian secara mendalam mengenai collective action NGO dalam pencegahan korupsi pengadaan barang/jasa pemerintah di Sulawesi Selatan.

\section{METODE PENELITIAN}

Artikel ini berangkat dari hasil penelitian yang menggunakan metode penelitian kualitatif. Teknik pengumpulan data yang digunakan yaitu, wawancara, observasi dokumentasi, dan studi dokumentasi dilakukan mengenai profil NGO-NGO yang terlibat secara tindakan kolektif, yaitu Koalisi Masyarakat Anti Korupsi (KMAK) Sulawesi, dalam mengawal korupsi pengadaan barang/jasa pemerintah. Wawancara dilakukan kepada NGO-NGO yang terlibat dalam mengawal kasus korupsi. Di bawah ini akan diuraikan empat hal terkait tindakan kolektif (collective action) NGO dalam mengawal korupsi pengadaan barang/jasa pemerintah di Sulawesi Selatan, yaitu, formasi kelompok, teknologi/metode agregasi, sumber anggaran, dan keragaman kepentingan. 


\section{HASIL DAN DISKUSI \\ a. Formasi Kelompok}

Dampak dari korupsi di sektor pengadaan barang/jasa pemerintah meyebabkan jembatan, jalan, kantor publik, barang/jasa publik yang cepat rusak dan rendahnya kualitas barang/jasa publik yang dinikmati masyarakat. Dengan demikian perlu keterlibatan masyarakat maupun LSM/NGO secara kolektif (collective action) sebagai wujud kepedulian untuk mencegah, mengontrol, mengendalikan dan mendorong pemberantasan korupsi di Sulawesi Selatan. Pentingnya keterlibatan elemen masyarakat dalam mendorong agenda pemberantasan korupsi di sektor pengadaan barang/jasa merupakan wujud pengawasan secara eksternal, sekaligus sebagai kekuatan penyeimbang dalam mengontrol kebijakan pemerintah, khususnya dalam pengadaan barang/jasa. Untuk itulah keterlibatan dan peran LSM menjadi sangat penting.

Di Sulawesi Selatan, begitu banyak jumlah LSM yang memiliki integritas dalam mengawal, mengontrol dan mencegah korupsi. LSM tersebut sampai sekarang masih konsisten dalam mengawal, mengontrol dan mencegah korupsi. Mereka membentuk koalisi sebagai satu bentuk gerakan secara kolektif (collective action) dalam mengawal dan mengadvokasi kasus-kasus korupsi. Adapun jumlah kelompok NGO yang terlibat dalam Koalisi Masyarakat Anti Korupsi (KMAK) Sulawesi dalam mengawal korupsi tersebut adalah sebagai berikut:

Tabel. 2

NGO/ LSM Anti Korupsi Di Sulawesi Selatan

\begin{tabular}{|c|c|c|c|c|}
\hline No. & Nama & Alamat Kantor & $\begin{array}{l}\text { Tahun } \\
\text { berdiri }\end{array}$ & Legalitas/ Badan Hukum \\
\hline 1 & $\begin{array}{l}\text { Komite } \\
\text { Pemantau } \\
\text { Legislatif } \\
\text { (KOPEL) } \\
\text { Indonesi }\end{array}$ & $\begin{array}{l}\text { Jl. Batua Raya } 9 \\
\text { No. } 3 \\
\text { (Makassar). Telp. } \\
\text { (0411) 491041 }\end{array}$ & $\begin{array}{l}10 \text { Maret } \\
2000\end{array}$ & 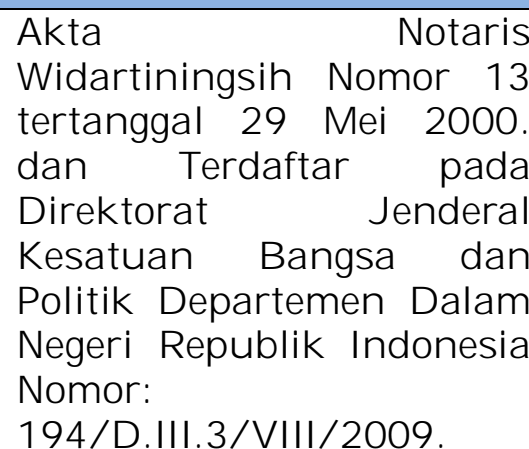 \\
\hline 2 & $\begin{array}{l}\text { Anti } \\
\text { Corruption } \\
\text { Committee } \\
\text { (ACC) } \\
\text { Sulawesi }\end{array}$ & $\begin{array}{l}\text { Jl. } \\
\text { Pangeran } \\
\text { Pettarani } \\
\text { Pettarani } \text { Renter } \\
\text { Blok A No. } 17 \\
\text { Makassar. Tlpn. } \\
\text { 0411-437312 }\end{array}$ & $\begin{array}{c}26 \\
\text { Desember } \\
1998\end{array}$ & 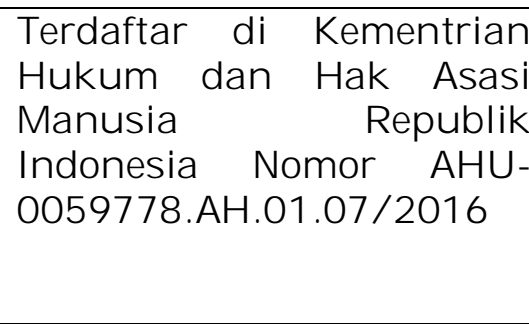 \\
\hline 3 & $\begin{array}{l}\text { Pendidikan } \\
\text { Anti } \\
\text { Korupsi } \\
\text { (PERAK } \\
\text { Institute) }\end{array}$ & $\begin{array}{l}\text { Kompleks } \\
\text { Maizonette. Jln. } \\
\text { Anggrek } 3 \text { No. } 2 \\
\text { Makassar } \\
\text { 90231. Tlpn } \\
\text { (0411) 441361 }\end{array}$ & $\begin{array}{l}21 \text { Agustus } \\
2000\end{array}$ & $\begin{array}{l}\text { Akta Notaris Harapan } \\
\text { Kanna, S.H. Nomor 04, } \\
\text { Tanggal } 26 \text { Agustus } 2010\end{array}$ \\
\hline 4 & Forum & Kompleks & 27 Mei & \\
\hline
\end{tabular}




\begin{tabular}{|c|c|c|c|c|c|}
\hline & $\begin{array}{c}\text { Informasi \& } \\
\text { Komunikas } \\
\text { i } \\
\text { Organisasi } \\
\text { Non } \\
\text { Pemerintah } \\
\text { Sulawesi } \\
\text { Selatan } \\
\text { (FIK } \\
\text { ORNOP } \\
\text { SULSEL) } \\
\end{array}$ & $\begin{array}{l}\text { Maizonette. Jln. } \\
\text { Anggrek } 3 \text { No. } 2 \\
\text { Makassar } \\
90231 . \quad \text { Tlpn } \\
\text { (0411) 441361 }\end{array}$ & 2000 & & \\
\hline 5 & $\begin{array}{l}\text { Swadaya } \\
\text { Mitra } \\
\text { Bangsa } \\
\text { (YASMIB) } \\
\text { Sulawesi }\end{array}$ & $\begin{array}{l}\text { Jln. Tamalate V } \\
\text { NO. } 48 \text { Makassar } \\
\text { 90222. Tlpn. } \\
(0411) \text { 845158 }\end{array}$ & $\begin{array}{c}20 \\
\text { November } \\
1999\end{array}$ & $\begin{array}{l}\text { Terdaftar di } \\
\text { Hukum dan } \\
\text { Manusia } \\
\text { Indonesia }\end{array}$ & $\begin{array}{r}\text { Kementrian } \\
\text { Hak Asasi } \\
\text { Republik }\end{array}$ \\
\hline
\end{tabular}

Sumber : diolah oleh penulis, 2017

NGO/LSM di atas merupakan kelompok NGO yang tergabung dalam Koalisi Masyarakat Anti Korupsi (KMAK) Sulawesi, yang mengawal kasus dugaan korupsi pembangunan mega proyek Center Point of Indoenesia (CPI) yang berada di sisi barat Pantai Losari Makassar Sulawesi Selatan. Model koalisi yang dibangun oleh NGO tersebut adalah "Koalisi Taktis" dimana terbentuknya berdasarkan ada isu korupsi yang menjadi perhatian luas publik Sulawesi Selatan.

"Selama ini koalisi yang kita bangun tidak permanen dan tidak ada aturan resmi seperti AD/ART. Koalisi yang kita bangun "koalisi taktis", koalisi taktis itu muncul ketika ada isu strategis yang menjadi perhatian publik secara luas. Tidak ada paksaan pada anggota koalisi untuk bergabung, tapi lebih kepada ketertarikan moril. Termasuk kasus Center Point of Indonesia (CPI) kita kawal atas nama KMAK.(Wawancara dengan Wakil Direktrur KOPEL Indonesia. Tanggal 14 Agustus, 2017).

Pola tindakan kolekif yang dibangun oleh NGO dalam mengawal kasus korupsi di Sulawesi Selatan lebih pada "koalisi taktis". Sehingga bisa dikatakan gerakan-gerakan yang dilakukan adalah gerakan spontan atas dasar solidaritas, keyakinan, adanya keprihatinan bersama dalam mengawal dan mengadvokasi kasus korupsi di Sulawesi Selatan. Gerakan koalisi yang dibangun oleh Koalisi Masyarakat Anti Korupsi (KMAK) Sulawesi adalah mengawal kasus Center Point of Indonesia (CPI). Koalisi ini tergabung dari berbagai NGO, diantaranya adalah KOPEL Indonesia, YASMIB Sulawesi, ACC Sulawesi, PeRAK Institue, dan FIK Ornop Sulsel. Koalisi Masyarakat Anti Korupsi (KMAK) melaporkan dugaan korupsi pembangunan Center Point of Indonesia (CPI) di KPK dengan subjek hukumnya Syahrul Yasin Limpo sebagai Gubernur Sulawesi Selatan (Kompas.com, 2016). Kawasan reklamasi CPI terletak di sebelah Barat Pantai Losari di Kecamatan Mariso Kota Makassar dengan luas 175, 23 Ha. Aktifitas reklamasi kawasan CPI sudah dilakukan oleh Pemerintah Provinsi Sulawesi Selatan melalui 3 SKPD terkait, yaitu, Dinas Tarkim, Dinas PSDA, dan Dinas 
Bina Marga dengan menggunakan Anggaran Pendapatan dan Belanja daerah (APBD) Provinsi Sulawesi Selatan sejak tahun 2008-2013.

Aktifitas reklamasi dengan menggunakan Anggaran Pendapatan dan Belanja Daerah (APBD) itu dikerjakan oleh 13 rekanan perusahaan. Pada tahun 2013 Provinsi Sulawesi Selatan kembali melakukan kerjasama dengan PT. Yasmin Bumi Asri selaku investor untuk melanjutkan pekerjaan reklamasi 175, 23 Ha yang sudah dilakukan sebelumnya oleh Pemerintah Sulawesi Selatan, dan sudah menghabiskan anggran Rp. 164 Miliar. Kasus dugaan korupsi mega proyek reklamasi Center Point of Indonesia (CPI) yang menyeret nama Gubernur Sulawesi Selatan, memang sangat ramai diperbincangkan dan mendapat perhatian publik Sulawesi Selatan secara luas. Hal demikian dikarenakan anggaran yang dikeluarkan dari APBD Sulawesi Selatan untuk mega proyek CPI mendapat penolakan dari berbagai kalangan masyarakat Sulawesi Selatan. Seperti aktivis lingkungan, LSM, akademisi, masyarakat umum, dan KMAK Sulawesi yang melakukan langkah hukum dengan melaporkan kasus tersebut di KPK.

Tabel. 3

Kasus dugaan Korupsi Pengadaan Barang/Jasa Kategori Konstruksi Center Point Of Indonesia (CPI) 2009-2015 di Sulawesi Selatan dalam Catatan Koalisi Masyarakat Anti Korupsi (KMAK) Sulawesi

\section{Collective Action}

LSM/NGO kasus

Center Point of

Indonesia (CPI)

Koalisi Masyarakat a). Proyek Center Point of Indonesia (CPI) tidak masuk Anti Korupsi (KMAK): dalam Rancangan Pembangunan Jangka Menengah Kopel Indonesia, Daerah (RPJMD) Sulawesi Selatan tahun 2008-2013;

Yasmib Sulawesi, b). Pembangunan proyek Center Point of Indonesia PeRAK Institute, ACC (CPI) telah menghabiskan uang rakyat dari Anggaran Sulawesi, FIK Ornop Pendapatan dan Belanja Daerah (APBD) sebesar Rp. Sulsel.

Temuan Dugaan Penyimpangan Kasus Center Point of Indonesia

164.148.560.000,00. Namun pekerjaan tersebut belum selesai dan proyek pembangunan reklamasi CPI tanpa ada izin reklamasi dan izin pelaksanaan reklamasi;

c). Anggaran yang telah dikeluarkan dalam pembangunan proyek Center Point of Indonesia (CPI) sebesar Rp. 164.148.560.000,00 sangat bertentangan dengan visi Pemerintah Provinsi Sulawesi Selatan tahun 2008-2013 "Sulawesi Selatan Sebagai Provinsi Sepuluh Terbaik dalam Pemenuhan Hak Dasar". Semestinya anggaran itu dialokasikan untuk pengentasan kemisikinan, pembangunan infrastruktur jalan, pelayanan kesehatan dan pendidikan di sejumlah daerah di Sulawesi Selatan; d). Sampai saat ini belum ada anggaran pemerintah pusat yang masuk dalam pembangunan proyek Center Point of Indonesia (CPI) Rp. 0, sangat kontradiktif dengan janji Gubernur Sulawesi Selatan pada tahun 2009, mengatakan pembangunan mega 
proyek CPI menggunakan anggaran dari pemerintah pusat. Hal ini berarti Gubernur Sulawesi Selatan sudah membuang-buang uang rakyat dari APBD sebesar Rp. 164 miliar karena sejak dari awal tidak pernah ada kepasatian anggaran dari pusat;

e). Gubernur Sulawesi Selatan melanggar UU No. 25 tahun 2004 dan Peraturan Daerah (Perda) tentang RPJMD Sulsel karena tetap melaksanakan pembangunan proyek Center Point of Indonesai (CPI) yang tidak masuk dalam RPJMD 2008-2013;

f). Izin reklamasi baru dimohonkan Pemerintah Provinsi Sulawesi Selatan kepada Menteri Kelautan dan Perikanan Republik Indonesia pada tahun 2013. Tanggal 23 September 2013 Pemerintah Sulsel menyampaikan surat No. 503/5361/TARKIM kepada Menteri Kelautan dan Perikanan perihal permohonan Rekomendasi Izin Lokasi Kawasan CPI di Makassar. Namun Menteri Kelautan dan Perikanan melalui surat tanggapannya No. B.682/MEN-KP/X/2013 tanggal 31 Oktober 2013 tidak mengeluarkan izin dan meminta kepada Pemerintah Sulsel dokumen-dokumen teknis reklamasi berdasarkan Perpres No. 122 tahun 2012. Sampai saat ini dokumen persyaratan yang diminta oleh Menteri Kelautan dan Perikanan tidak pernah dipenuhi oleh Pemerintah Provinsi Sulawesi Selatan;

g). Gubernur Sulawesi Selatan melakukan "pembangkangan" karena mengeluarkan sendiri izin reklamasi pada tanggal 1 November 2013 dengan No. 644/623/Tarkim/2013. Padahal mengacu PP No. 26 tahun 2008 tentang Rencana Tata Ruang Wilayah Nasional, terkait Penetapan Kawasan Strategis Nasional. Kawasan CPI yang terletak di Kota Makassar masuk dalam Kawasan Strategis Nasional. Sehingga berdasarkan pasal 16 ayat (2) Perpres No. 122 tahun 2012, izin lokasi dan izin pelaksanaan reklamasi untuk Kawasan Strategis Nasional dikeluarkan oleh Menteri, bukan Gubernur apalagi Walikota.

h). Tahun 2013 (periode kedua Gubernur Syahrul Yasin Limpo) pembangunan kembali dilanjutkan. Pemerintah Provinsi Sulawesi Selatan menggandeng PT. Yasmin Bumi Asri sebagai pihak ketiga untuk melanjutkan reklamasi pembangunan CPI melalui MoU No. 252/VII/PEMPROV/2013 dan No. 231/YBA/VII/2013 Tentang Reklamasi Kawasan Center Point of Indonesia (CP) di Kota Makassar Sulawesi Selatan. berdasarkan MoU itulah diketahui baru diurusnya semua administrasi perizinan dan lain-lainnya oleh PT Yasmin Bumi Asri. Reklamasi kali 
ini tidak menggunakan APBD, namun hasil reklamasi/penimbunan dibagi antara PT. Yasmin Bumi Asri dengan Pemerintah Sulsel, dari $157 \mathrm{Ha}$ yang ditimbun PT. Yasmin Bumi Asri mendapat bagian $100 \mathrm{Ha}$ dan Pemerintah Sulsel 57 Ha. Bagian tersebut sudah termasuk di dalamnya yang sudah ditimbun sejak tahun 2009 oleh sedikitnya 13 perusahan rekanan pihak ketiga Pemerintah Sulsel yang sudah menghabiskan anggaran dari APBD Rp. 164 miliar.

i). Meskipun MoU dilakukan antara Pemprov. Sulsel dengan PT. Yasmin Bumi Asri, namun faktanya yang mengerjakan proyek reklamsi tersebut adalah PT. Ciputra, hingga selesai pekerjaan dan pembagian lahan hasil reklamsi PT. Ciputra masih terus berperan dan sampai saat ini, PT. Ciputra telah melakukan pemasaran lahan komersial CPI. Tidak sampai disitu PT. Ciputra bersama PT. Yasmin Bumi Asri tidak mampu melakukan pekerjaan reklamasi dan PT Yasmin Bumi Asri dan PT. Ciputra mengadakan kontrak kerjasama dengan sebuah perusahaan internasioanal yaitu PT. Boskalis pada hari kamis 24 maret 2016 di BDS Tower, Kuningan DKI Jakarta untuk membicarakan kelanjutan reklamasi tersebut.

Sumber : diolah dari hasil Investigasi KMAK, 2017

Dari beberapa poin kejanggalan yang dipaparkan di atas dalam proses pembangunan mega proyek Center Point of Indonesia (CPI) dari tahun 20092015 menjadi pertimbangan KOPEL Indonesia dan Koalisi Masyarakat Anti Korupsi (KMAK) membawa kasus tersebut ke ranah hukum untuk ditandakalanjuti. Hal tersebut dilatarbelakangi karena ada dugaan penyimpangan mulai dari tahap persiapan, proses, maupun tahap pelaksanaannya. Langkah demikian dilakukan demi penyelamatan uang rakyat dari praktek tindakan Korupsi, Kolusi dan Nepotisme (KKN). Kasus tersebut sudah diserahkan ke KPK walaupun sampai saat ini belum ada tindakan dari KPK (Kompas.com. 2016).

Upaya mengawal dan mengadvokasi kasus korupsi di Sulawesi Selatan, khususnya kasus Center Point of Indoensia (CPI). LSM-LSM yang tergabung dalam Koalisi Masyarakat Anti Korupsi (KMAK) Sulawesi selalu melakukan pertemuan-pertemuan untuk membahas dan merencanakan bentuk aksi yang akan dilakukan dalam menentukan arah perjuangan dan merumuskan kebijakan, pola dan bentuk gerakan. Terdapat dua model pertemuan-pertemuan yang dilakukan dalam mengawal kasus korupsi di Sulawesi Selatan.

1. Pertemuan Non Formal

Rutinitas pertemuan yang dilakukan oleh koalisi NGO dalam pertemuan non formal ini sangat intens, dan pertemuan dilakukan bisa berupa pertemuan langsung seperti di warung kopi, dan sejenisnnya, dan juga Pertemuan tidak langsung lewat diskusi melalui media sosial (whatshApp, BBM, dll.). 


\section{Pertemuan Formal}

Pertemuan formal biasanya berupa pertemuan resmi dari lembaga atau LSM yang inisiatif untuk melakukan rapat konsuldasi secara resmi, dengan mengrimkan surat secara resmi kepada anggota lembaga atau LSM-LSM yang tergabung dalam koalisi anti korupsi, dan setiap lembaga mengirim delegasi 1 (satu) orang untuk mewakili lembaga masingmasing.

NGO yang tergabung dalam Koalisi Masyarakat Anti Korupsi (KMAK) Sulawesi memang sangat rutin melakukan pertemuan untuk membahas pola gerakan, dan model gerakan yang dilakukan dalam mengawal kasus dugaan Korupsi proyek Center Point of Indoenesia. Rutinitas pertemuan tersebut selain untuk memperkokoh hubungan emosional sesama NGO penggiat korupsi, juga untuk menyatukan satu pandangan dan visi yang sama. Rutinitas pertemuan menjadi kunci untuk menentukan arah perjuangan yang dilakukan oleh NGO yang tergabung dalam Koalisi Masyarakat Anti Korupsi (KMAK) yang mengawal kasus-kasus korupsi di Sulawesi Selatan. Rutinitas pertemuan juga untuk menyatukan gagasan diantara anggota koalisi sehingga perjuangan yang dilakukan mencapai tujuan sesuai harapan bersama dari koalisi yang dibangun. Sebagaimana disampaikan (Hadiz dalam Widoyoko, 2009). Perjuangan melawan korupsi oleh NGO merupakan bagian pertempuran melawan predator. Untuk itulah kesamaan tujuan, cita-cita bersama harus dijaga, dan aksi-aksi yang efektif, berkelanjutan harus disertai dengan konsep dan pertemuan-pertemuan yang mengahasilkan gagasan yang matang.

\section{b. Teknologi/Metode Agregasi}

NGO yang ingin mencapai tujuannya tergabung dalam Koalisi Masyarakat Anti Korupsi (KMAK) Sulawesi, memanfaatkan media masa (cetak dan elektronik) untuk mengagregasi kepentingannya, dengan mempublikasikan hasil pemantauan, investigasi dan temuannya dalam kasus dugaan korupsi CPI. Media dimanfaatkan sebagai upaya membagun opini publik, sekaligus menyebarkan informasi kepada publik terkait pelanggaran yang dilakukan Pemerintah Provinsi Sulawesi Selatan. Keterlibatan media dalam agenda gerakan anti korupsi yang dimanfatakan oleh kelompok-kelompok NGO yang tergabung Koalisi Masyarakat Anti Korupsi (KMAK) dalam mengadvokasi kasus korupsi. Oleh karena itu, hadirnya media dalam agenda melawan korupsi membuat isu korupsi yang belum tuntas terus dimuat, disajikan dan diberitakan dalam bentuk yang lain oleh media cetak maupun media elektronik.

"Salah satu kampanye untuk mempengaruhi opini publik itu adalah media, opini publik terhadap isu yang kita angkat. Karena begini kita tidak mampu untuk menjelaskan kepada publik satu per satu atau kelompokkelompok yang begitu banyak tanpa melalui media. Jadi media massa ini, baik cetak maupun elektronik menjadi bagian yang turut membantu gerakan advokasi Koalisi Masyarakat Anti korupsi (KMAK) dalam mengawal kasus CPI. Kasus CPI sejak tahun 2009 dan sampai sekarang masih tetap diberitakan, dan dikemas dalam bentuk yang lain oleh media untuk dituntaskan...”. (Wawancara dengan Juru Bicara KMAK Sulawesi. Tanggal 14 Agustus, 2017).

Peran media yang sangat penting bagi keberlangsungan gerakan-gerakan NGO yang mengawal dan melawan korupsi. Massifnya pemberitaan media lokal terkait isu dugaan korupsi Center Point of Indonesia (CPI) di Sulawesi Selatan 
yang dikawal oleh NGO yang tergabung dalam Koalisi Masyarakat Anti Korupsi (KMAK) Sulawesi, membuat kasus tersebut masih terus diberitakan dan diperkarakan untuk dituntaskan. Pemanfaatan media untuk menyebarkan isu dugaan korupsi CPI merupakan bagian strategi untuk mendapatkan perhatian publik yang lebih luas, sehingga terbentuk kesadaran kolektif dari berbagai elemen masyarakat untuk sama-sama mengawal kasus tersebut yang sangat merugikan masyarakat Sulawesi Selatan.

Massifnya pemberintaan media terkait dugaan korupsi pembangunan Center Point of Indonesia (CPI) mengindikasikan bahwa kampanye yang dilakukan Koalisi Masyarakat Anti Korupsi (KMAK) Sulawesi, menyebar luas pada lapisan masyarakat dan sekaligus mempengaruhi lembaga penegak hukum dan lembaga pengawas pemerintah untuk mengusut kasus dugaaan korupsi CPI. Dalam sebuah berita di media online. Kejakasaan tinggi SulSel-Bar tengah menurunkan tim khusus untuk mengusut dugaan korupsi proyek Center point of Indoensia (CPI) atas laporan dari KMAK Sulawesi, dan berita yang terus beredar terkait CPI (Harian Berita Kota Makassar, 2016). Lembaga pengawas dan pengaduan Ombudsaman Perwakilan Sulawesi Selatan, setelah ada laporan bukti-bukti yang disampaikan KOPEL Indonesia dan KMAK Sulawesi, juga ikut melirik kasus CPI dan bergerak cepat dan melakukan verifikasi dan klarifikasi data yang berkaitan dengan dugaan korupsi proyek Center Point of Indonesia (CPI) (Harian berita Kota makassar, 2017). Langkah-langkah yang pernah ditempuh oleh Koalisi Masyarakat anti Korupsi (KMAK) Sulawesi dimuat dalam bentuk berita adalah sebagai berikut:

Tabel. 4

Metode Agregasi Koalisi Masyarakat Anti Korupsi (KMAK) yang Dimuat Dalam Bentuk Berita Oleh Media Terkait Dugaan Korupsi Mega Proyek Center Point of Indonesia (CPI)

\begin{tabular}{l} 
Metode Agregasi \\
\hline Press Release: berita singkat \\
yang berisi tentang hasil \\
kegiatan pemantauan yang \\
dilakukan NGO/LSM
\end{tabular}

kemudian dimuat oleh media Frekuensi Prosentase (\%)

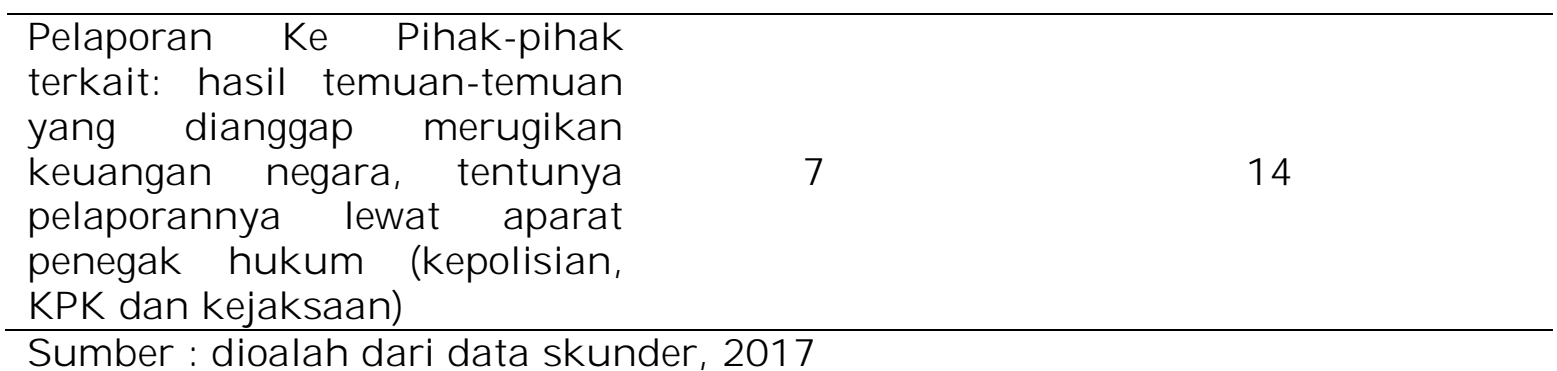

Sumber : dioalah dari data skunder, 2017 
Pemberitaan langkah atau metode yang dilakukan oleh Koalisi Masyarakat Anti Korupsi (KMAK) Sulawesi dalam mengawal dan mengadvokasi kasus dugaan korupsi dan penyalahgunaan wewenang oleh Pemerintah Sulawesi Selatan, terkait pembagunan Mega Proyek CPI di pessisir Barat Pantai Losari Kota Makassar Sulawesi Selatan. Massifnya pemberitaan media dianggap efektif oleh Koalisi Masyarakat Anti korupsi (KMAK) Sulawesi untuk membangun opini publik agar setiap lembaga penegak hukum serius menangani kasus tersebut. Pemberitaan tersebut sekaligus untuk memberikan informasi kepada publik, bahwa pembangunan CPI oleh Pemerintah Provinsi Selatan sangat berdampak buruk bagi masyarakat Sulawesi Selatan, khususnya masyarakat pesisir yang berada disekitar pembangunan mega proyek CPI.

\section{c. Sumber Anggaran}

Demi menjaga keseimbangan roda organisasi tetap berjalan, setiap NGO membutuhkan alokasi anggaran sebagai alat perencanaan kegiatan yang akan dilakukan dan/atau untuk program-program yang akan dijalankan. Oleh karena itu, finansial atau sokongan dana menjadi begitu penting dalam setiap operasional NGO. Setiap NGO secara umum untuk alokasi anggarannya sudah diatur dalam pedoman organisasi masing-masing. Namun bagaimana pengalokasian anggaran ketika NGO yang tergabung dalam suatu koalisi atau dalam tindakan kolektif (colletive action) mengawal dan mengadvokasi kasus korupsi yang sedang ditangani secara bersama. Dalam melakukan aksi secara bersama (collective action) mengawal dan mengadvokasi kasus korupsi. Sumber anggaran yang digunakan dalam setiap aktivitas koalisi NGO yang tergabung Koalisi Masyarakat Anti Korupsi (KMAK) khusunya mengadvokasi kasus dugaan korupsi proyek Center Point of indonesia (CPI), sumber anggaran berasal dari iuran anggota koalisi. Ada beban biaya yang ditanggung secara bersama (swadaya), dimana setiap anggota koalisi mengumpulkan dana sesuai kebutuhan operasaional lembaga.

Kebutuhan pendaanaan NGO yang tegabung dalam Koalisi Masyarakat Anti Korupsi (KMAK) Sulawesi yang dialokasikan dalam mengawal kasus dugaan korupsi proyek CPI meliputi: rapat/petemuan secara formal, rapat/ pertemuan non formal, pemantauan, investigasi, dll. Namun berbeda ketika NGO mengerjakan program/kegiatan sendiri-sendiri, sumber dana yang didapat didukung oleh lembaga donor internasional.

Tabel. 5

Kegiatan/ Program Pencegahan Korupsi NGO YASMIB Sulawsi Pembiyaaannya Didukung Oleh Lembaga Donor Internasional

\begin{tabular}{|c|c|c|}
\hline No. & Nama Kegiatan & Lembaga Donor \\
\hline 1. & $\begin{array}{lr}\text { Sosialisasi Penggunaan } & \text { Website } \\
\text { Opentender.net } & \text { Dalam } \\
\text { Memantau Pengadaan } & \text { Barang/ } \\
\text { Jasa Pemerintah } & \end{array}$ & ICW dan The Asian Foundation (TAF) \\
\hline 2. & $\begin{array}{l}\text { Pelatihan Penggunaan Aplikasi } \\
\text { Opentender.net Bagi Aktivis NGO } \\
\text { dan Jurnalis Dalam Memantau } \\
\text { Pengadaan } \\
\text { JasaPemerintah }\end{array}$ & $\begin{array}{l}\text { Depertement of Foreign Affairs, Trade } \\
\text { and Devolepment (DFATD) }\end{array}$ \\
\hline 3. & $\begin{array}{llr}\begin{array}{l}\text { Diskusi } \\
\text { Meeting }\end{array} & \text { Multi } & \begin{array}{r}\text { Stakeholder } \\
\text { Pemantauan }\end{array}\end{array}$ & ICW dan The Asian Foundation (TAF) \\
\hline
\end{tabular}




\begin{tabular}{|c|c|c|}
\hline & \begin{tabular}{llr} 
Pelaksanaan & \multicolumn{2}{c}{ Pengadaan Barang } \\
dan jasa & Secara Elektronik \\
Pemerintah & Provinsi & Sulawesi \\
Selatan & & \\
\end{tabular} & \\
\hline 4. & $\begin{array}{l}\text { Pelatihan Pemantauan } \\
\text { Pengadaan Barang dan Jasa } \\
\text { Secara Elektronik Bagi CSO di } \\
\text { Sulawesi Barat }\end{array}$ & $\begin{array}{l}\text { Depertement of Foregn Affairs, Trade } \\
\text { and Devolepment (DFATD) }\end{array}$ \\
\hline
\end{tabular}

Sumber : Progres Report YASMIB Sulawesi, 2017.

Tabel. 6

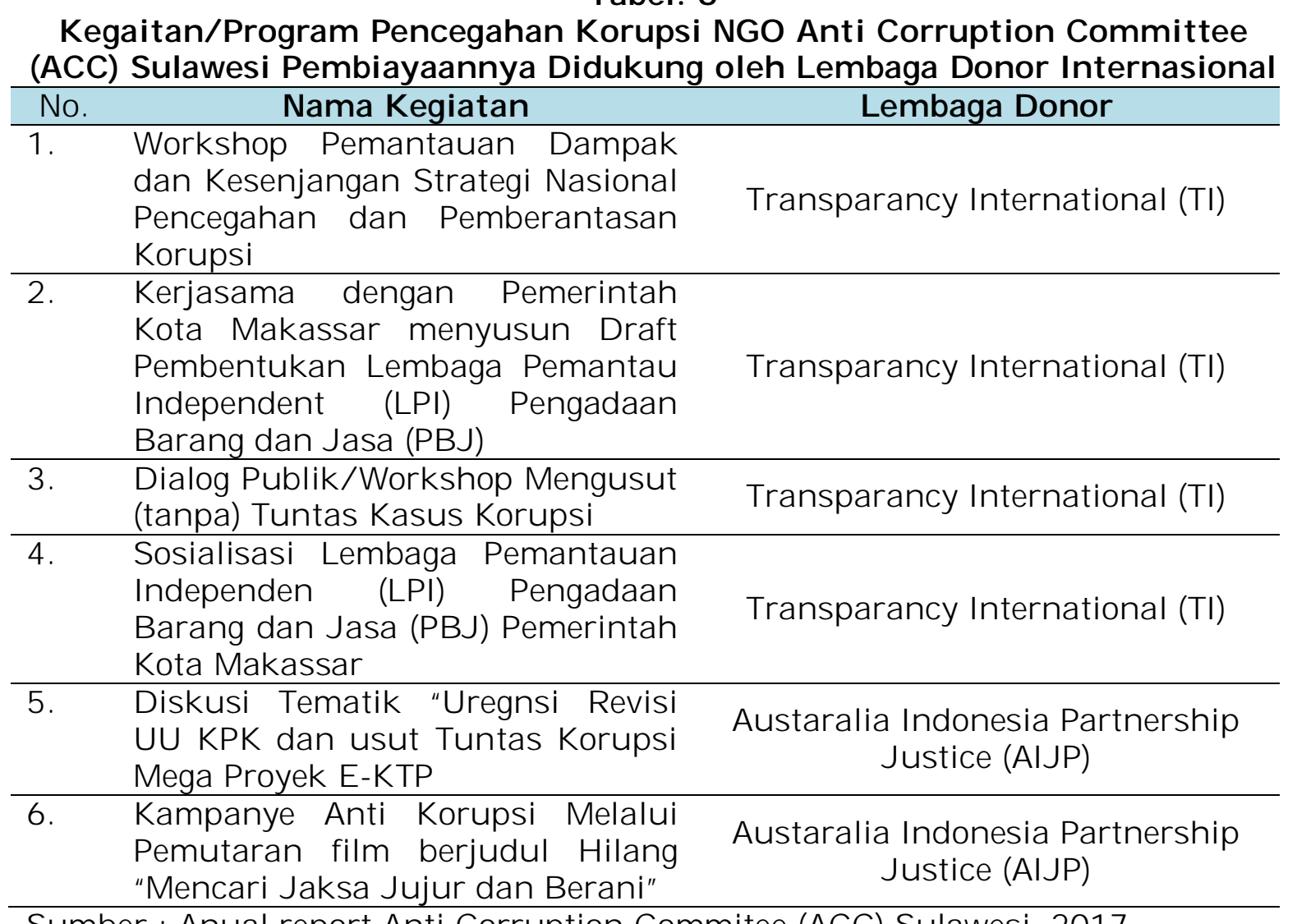

Sumber : Anual report Anti Corruption Commitee (ACC) Sulawesi, 2017

Tabel di atas menjelaskan tentang contoh program/kegiatan ACC Sulawesi dan YASMIB Sulawesi dalam melaksankan program/kegiatan pencegahan korupsi pembiyaannya didukung oleh lembaga donor internasional. Hampir semua program/kegiatan NGO yang sifatnya soft (pencegahan korupsi) meliputi diskusi, pelatihan, kampanye melalui pemutaran film, dan kerjasama dengan pemerintah daerah dalam pencegahan korupsi. Khusunya di sektor pengadaan barang/jasa pemerintah yang dilakukan oleh masing-masing NGO. Sumber anggarannya berasal dari lembaga donor internasional. Pemnafaatan anggaran dari lembaga donor internasioanl sudah menjadi kebutuhan NGO lokal dalam melaksanakan kegiatan/program kerjanya. Hal tersebut dikarenakan NGO memiliki keterbatasan keuangan secara internal. 
Sumber keuangan lembaga donor internasional menjadi solusi alternatif bagi NGO lokal dalam menyukseskan agenda-agenda pencegahan korupsi di Sulawesi Selatan. Ketergantungan NGO lokal terhadap lembaga donor internasional sangat tinggi dalam hal pendanaan. Hal tersebut terbukti hampir seluruh program/kegiatan NGO sumber anggarannya didukung oleh lembaga donor internasioanl. Dana memainkan peran penting untuk kebutuhan menyukseskan kegiatan/program NGO, termasuk dalam hal kegiatan aksi, opersional, gaji dll. NGO selalu menempatkan dana sebagai bagian yang utama dari keberadaan lembaga. Dana menjadi hal penentu bagi keberlangsungan berjalan atau tidaknya aktivitas NGO (Fakih, 2000, Assadi et, 2009).

Menarik untuk diperhatikan ketika komitmen NGO dalam mengawal kasus korupsi secara tindakan kolektif dengan tidak menggunakan anggaran dari luar. Hal tersebut sebagai upaya menjaga kemurnian gerakan yang dibangun. Salah satu contoh tindakan kolektif NGO, dimana beban pembiayaannya ditanggung secara bersama (swadaya) adalah mengawal kasus dugaan korupsi pembangunan mega proyek Center Point Indonesia (CPI). Gerakan tersebut merupakan gerakan masyarakat sipil yang berjuang untuk kepentingan masyarakat Sulawesi Selatan. Gerakan anti korupsi yang dilakukan oleh sejumlah NGO yang tergabung dalam Koalisi Masyarakat Anti Korupsi (KMAK) Sulawesi bisa disebut new soscial movement karena tujuannya memberantas korupsi dan mendorong berbagai program pencegahan korupsi.

\section{d. Komposi Kelompok}

Kerjasama yang baik hanya dengan berkolaborasi untuk memastikan bahwa tindakan kolektif tetap berjalan. Namun terkadang setiap anggota kelompok dalam suatu koalisi memiliki kepentingan masing-masing sesuai tipe kelompoknya, dengan kepentingan yang beragam. Keragaman kepentingan anggota kelompok yang tergabung dalam suatu koalisi sangat mempengaruhi keberhasilan tindakan kolektif dalam mengawal kasus korupsi secara bersama, semakin beragam kepentingan anggota kelompok koalisi akan semakin sulit untuk mencapai tindakan kolektif. Koalisi Masyarakat Anti korupsi (KMAK) Sulawesi yang pernah dibentuk oleh NGO di Sulawesi Selatan merupakan salah satu gerakan masyarakat sipil yang bergerak secara tindakan kolektif (collective action) dalam mengawal dan mengadvokasi kasus-kasus korupsi di Sulawesi Selatan.

Aksi bersama NGO yang tergabung dalam Koalisi Masyarakat Anti korupsi (KMAK) Sulawesi dalam membongkar dan mengadvokasi kasus dugaan korupsi pembangunan CPI yang melibatkan nama Gubernur Sulawesi Selatan, merupakan reaksi perlawanan terhadap kejahatan korupsi oleh NGO. Dalam koalisi anti korupsi yang dibangun oleh NGO-NGO di Sulawesi Selatan sangat memperhatikan seluruh kepentingan anggota kelompok, sehingga kerja-kerja advokasi berjalan lancar dan sangat mementingkan kepentingan bersama. Sehingga tidak terjadi keragaman kepentingan maupun rivalitas diantara kelompok yang tergabung dalam Koalisi masyarakat Anti korupsi (KMAK) Sulawesi.

Solidnya gerakan yang dibangun oleh NGO-NGO yang tergabung dalam kaolisi Masyarakat anti Korupsi (KMAK) Sulawesi dalam mengadvokasi kasus dugaan korupsi CPI merupakan bagian dari adanya komitemen dan keyakinan bersama dari seluruh anggota koalisi untuk menuntaskan kasus tersebut. 
Walaupun kasus dugaan korupsi CPI belum ada titik terangnya dalam proses hukum, namun KMAK memiliki keyakinan, perjuangan mereka tidak akan siasia. Tekanan-tekanan yang terus dilakukan melalui pelaporan kepada pihakpihak yang berwenang (KPK, Kejaksaan, Ombudsman dan DPR-RI). Keterlibatan media yang massif, yang terus memberitakan kerja-kerja advokasi KMAK membuat mereka optimis bahwa kasus dugaan korupsi CPI bisa dituntaskan secara hukum. Namun ketika hal tersebut tidak terjadi, mereka akan terus mengawal kasus tersebut sebagai bagian tanggung jawab sosial terhadap masyarakat dan kontrol sosial terhadap Pemerintah.

Suksesnya tindakan kolektif (collective action) dalam mengawal korupsi terletak pada kepercayaan dan komitmen dari seluruh anggota kelompok yang bergabung dalam suatu koalisi. Sebagaimana yang disampaikan Gilbert (dalam Alto, 2010) tindakan kolektif hanya bisa tercapai jika didalamnya terdapat keyakinan bersama dan tindakan secara bersama. Ada dua hal yang menjadi dasar mengapa NGO-NGO yang tergabung dalam Koalisi Masyarakat Anti Korupsi (KMAK) Sulawesi yang saling bekerjasama membongkar dan mengadvokasi kasus dugaan korupsi CPI. Pertama, untuk menghindari gangguan yang berdampak negatif dari kelompok-kelompok yang merasa dirugikan oleh kelompok KMAK yang membongkar kasus tersebut, dengan berkolisi dan aksi bersama yang solid, kelompok lawan sulit untuk menggangu kelompok KMAK. Kedua, adanya keinginan untuk memecahkan masalah secara bersama dan mewujudkan tujuan bersama dalam memberatas korupsi.

\section{KESIMPULAN}

Collective action NGO atas nama Koalisi Masyarakat Anti Korupsi (KMAK) Sulawesi merupakan satu contoh keterlibatan kelompok masyarakat sipil seperti NGO dalam upaya pemberantasan praktik korupsi public procurement. NGO memiliki peran penting dalam kerja-kerja pencegahan korupsi, khususnya korupsi pengadaan barang/jasa Pemerintah. Keterlibatan media menjadi kunci suksesnya gerakan yang dibangun dalam mengadvokasi kasus korupsi pengadaan barang/jasa kategori jasa Kontruksi, Center Point of Indonesia (CPI), dan sekaligus menjadi metode agregasi untuk mencapai tujuannya. Massifnya pemberitaan media atas laporan, pemantauan dan diskusi-diskusi yang dilakukan oleh kelompok Koalisi Masyarakat Anti Korupsi (KMAK) Sulawesi membuat sejumlah lembaga formal negara ikut melirik kasus CPI tersebut. Sumber anggaran yang digunakan dalam kegiatan mengadvokasi kasus CPI adalah murni dari swadaya dari anggota Koalisi Masyarakat Anti Korupsi (KMAK) sulawesi. Anggaran tersebut digunakan untuk kebutuhan operasional. Solidnya gerakan yang dibangun oleh Koalisi Masyarakat Anti Korupsi (KMAK) Sulawesi bertransformasi menjadi gerakan masyarakat sipil yang mempertahankan tujuan bersama. Sehingga dalam gerakan-gerakan advokasi yang dilakukan tidak terjadi keragaman kepentingan dan tidak ada rivalitas antar kelompok dalam tubuh KMAK. Pola koalisi yang dibangun KMAK berdasarkan kepemimpinan kolektif dan pengambilan keputusan secara bersama dengan kepercayaan dan etika berjaringan yang dipahami bersama. 


\section{DAFTAR PUSTAKA}

Alto, Ernest. (2011). Aspek Hukum Perananan perusahaan Dalam Aksi bersama Melawan Korupsi (Doctoral Disertation, Universitas Indonesia. Fakultas Hukum).

Assadi, H., Dharmawan, A. H., \& Adiwibowo, S. (2009). Independensi Lembaga Swadaya Masyarakat (LSM) di Tengah Kepentingan Donor. Sodality: Jurnal Sosiologi Pedesaan, 3(2).

Astuti, P. (2014). Lsm Dan Gerakan Anti Korupsi: Analisis Peran Lsm Dalam Membangun Kesadaran Anti Korupsi Dan Dalam Memerangi Tindak Pidana Korupsi Di Kota Semarang. Jurnal Ilmu Sosial, 13(2), 51-62.

Barnaud, C., Corbera, E., Muradian, R., Salliou, N., Sirami, C., Vialatte, A., ... \& Reyes-García, V. (2018). Ecosystem services, social interdependencies, and collective action: a conceptual framework. Ecology and Society, 23(1), 1-14.

Butarbutar, R. (2018). Pertanggungjawaban Korporasi Dalam Tindak Pidana Korupsi Pengadaan Barang Dan Jasa Pemerintah Di Bidang Konstruksi. Jurnal Penelitian Hukum Legalitas, 9(1), 51-66.

Fakih, Mansour, 1996. Masyarakat Sipil Untik Transformasi Sosial, Pergolakan Ideologi LSM Indonesia. Pustaka Pelajar. Yogyakarta.

Olson, M. (2008). Collective action. The New Palgrave Dictionary of Economics: Volume 1-8, 876-880.

Prasetia, Jaya, Eko. (2015). Peran Lembaga Swadaya Masyarakat Investigation Corruption Transparan Indpennden (ICTI) Dalam Pemberantasan Korupsi Pada Instansi Pemerintah Kota Tanjung. Naskah Publikasi, Fakultas Ilmu Sosial dan ilmu Politik Universitas Maritim Raja Haji Tanjung Pinang, 2015.

Sandler, T. (2015). Collective action: fifty years later. Public Choice, 164(3-4), 195-216.

Setyadiharja, R., Budiman, S., Karim, Z. A., Matridi, R. A., \& Nurmandi, A. (2014). E-procurement system technology: an analysis in electronic procurement service unit (LPSE) of Kepulauan Riau Province. The Asian Journal Of Technology Management, 7(2), 93.

\section{Dokumen-dokumen}

Anual report Anti Corruption Committe (ACC) Catatan Akhir Tahun Anti Corruption Committee (ACC) Sulawesi Korupsi Pengadaan Barang/ Jasa di Provinsi Sulawesi Selatan Tahun 2013-2016.

Anual report Anti Corruption Commitee (ACC) Sulawesi, 2017. Kegaitan/Program Pencegahan Korupsi NGOAnti Corruption Committee (ACC) Sulawesi Pembiayaannya di Dukung oleh Lembaga Donor Internasional.

Progres Report YASMIB Sulawesi, 2017. Kegiatan/Program Pencegahan Korupsi NGO YASMIB Sulawsi Pembiyaaannya di Suport Oleh Lembaga Donor Internasional.

\section{Wawancara}

Wawancara dengan Wakil Direktrur KOPEL Indonesia. Tanggal 14 Agustus, 2017.

Wawancara dengan Juru Bicara KMAK Sulawesi. Tanggal 14 Agustus, 2017. 